\title{
Inheritance Pattern and Gene Action of Brown Planthopper (Nilaparvata lugens Stäl.) Resistance in Newly Identified Donors of Rice (Oryza sativa L.)
}

\author{
S.A. RATHER* and I. DEO \\ Department of Genetics \& Plant Breeding, G.B. Pant University of Agriculture and Technology, \\ Pantnagar - 263145, Uttarakhand, India \\ (Received 26 February 2018; Accepted 13 April 2018; \\ Communicated by P.S. Baenziger)
}

\begin{abstract}
Brown planthopper (BPH) is one of the destructive insect pests causing significant yield losses in rice. BPH causes direct damage to the rice plants by sucking the sap from phloem, causing hopper burn and transmitting viral diseases like grassy and ragged stunt viruses. Several resistant donors have been identified from time to time, but the new biotypes of the pest arise to defeat the extended use of resistance genes in a single variety. This necessitates the regular identification of new resistant donors along with their nature of inheritance and gene action controlling the resistance. Knowing the inheritance pattern, gene action and number of genes controlling a trait helps the plant breeders to plan the effective breeding approaches for crop improvement. The present investigation was hence carried out to know the inheritance pattern, gene action and number of genes controlling BPH resistance in newly identified sources. The results indicated that the BPH resistance in PHS 29 genotype is under the control of single recessive gene. Whereas, it is controlled by two recessive genes in MRST 3 genotype. This reveals that relatively higher population size will be required to recover desirable segregants in the segregating populations involving MRST 3 genotype as one of the parents as compared to that involving PHS 29 genotype as parent. Since, the resistance in both the cases being recessive in nature, the trait will hence show significant additive effect, indicating that pure line development will be desirable for improvement of such a trait.
\end{abstract}

Keywords: BPH, resistance, inheritance, gene action, rice

\section{Introduction}

Planthoppers are phloem feeders, belonging to superfamily Fulgoroidea and order Hemiptera. The most economically vital family is Delphaciedae considering the mechanical damage it causes to rice crop and the transmission of various viral diseases (Dupo and Barrion 2009). Among planthoppers, brown planthopper (BPH) is one of the most vicious insect pests causing considerable yield losses in most of the rice cultivars of Asia (Sogawa et al. 2003). BPH, Nilaparvata lugens (Homoptera: Delphacidae) induces direct damage to the plant by sucking the sap from phloem, causing hopper burn and transmitting

*Corresponding author; E-mail: shoukat.pbg@gmail.com 
important viral diseases such as ragged and grassy stunt viruses. Even if the planthopper population is not significant enough to kill the plants, BPH feeding may still lead to considerable yield losses (Watanabe et al. 1997). More than $28 \%$ of the total dry matter of rice plants can be consumed by $\mathrm{BPH}$, if infested during reproductive phase of rice crop (Sogawa et al. 1994). Destructive damages due to BPH in recent years have been reported in China, Japan, Korea and Vietnam. In China, yield loss of about 2.7 million tons of rice due to BPH damage has been noticed during 2005 and 2008, while a yield loss of 0.4 million tons was reported in Vietnam due to ragged stunt and grassy stunt viruses transmitted by BPH (Brar et al. 2010). In India, heavy infestation of BPH was reported during 2007 in parts of Cauvery command area in Karnataka and during 2008 in Haryana, Punjab and Delhi states (Gowda 2009).

Advances in modern technologies have led to several control measures to minimize yield losses due to BPH infestation. But to develop a sustainable insect pest management system, there is a need to find correct balance among breeding and management strategies in order to keep the pest population under economic threshold levels (Bosque-Perez and Buddenhagen 1992). Conventional procedures to reduce damage caused by BPH include the use of chemical insecticides but this is costly, ineffective under some weather conditions and the chemicals can kill BPH predators, such as Anagrus nilaparvatae and Creontiades dilutes (Wang et al. 2008), which may lead to increased pest incidence as well as evolution of pesticide resistant BPH biotypes (Tanaka and Matsumura, 2001). Host plant resistance is by far the most valuable and environment friendly approach to prevent the losses caused by BPH, thereby enhancing yield potential of crop plants (Jena et al. 2006). In order to breed for BPH resistant rice varieties, it is imperative to recognize BPH resistance genes from diverse sources and integrate them into high yielding but susceptible rice cultivars. Before planning of any breeding programme for a given trait, it is quite necessary to know the nature of inheritance, gene action and number of genes controlling it. This helps breeders to decide the approach to be used for effective genetic advance and the size of the segregating generations required to recover the desirable plant types (recombinants). Keeping this in view, the present investigation entitled was carried out to determine the nature of inheritance and gene action of BPH resistance in newly identified sources from the cultivated gene pool of rice (Oryza sativa L.).

\section{Materials and Methods}

The rice germplasm that was subjected to screening for BPH resistance using Standard seed box screening technique of Heinrichs et al. (1985) under controlled conditions. The germplasm included 44 advanced rice lines $\left(\mathrm{F}_{6} / \mathrm{F}_{7}\right.$ generation) and six stable lines along with susceptible check, that is, Taichung Native 1 (TN 1) (Table S1*).

The BPH susceptible genotypes, TN 1 and Pusa Basmati 1 were crossed with identified BPH resistant genotypes PHS 29 and MRST 3, respectively to produce the $F_{1}$. The $F_{1}$ derived from TN $1 \times$ PHS 29 cross was advanced to produce $\mathrm{F}_{2}$ generation. Whereas, the

\footnotetext{
*Further details about the Electronic Supplementary Material (ESM) can be found at the end of the article.
} 


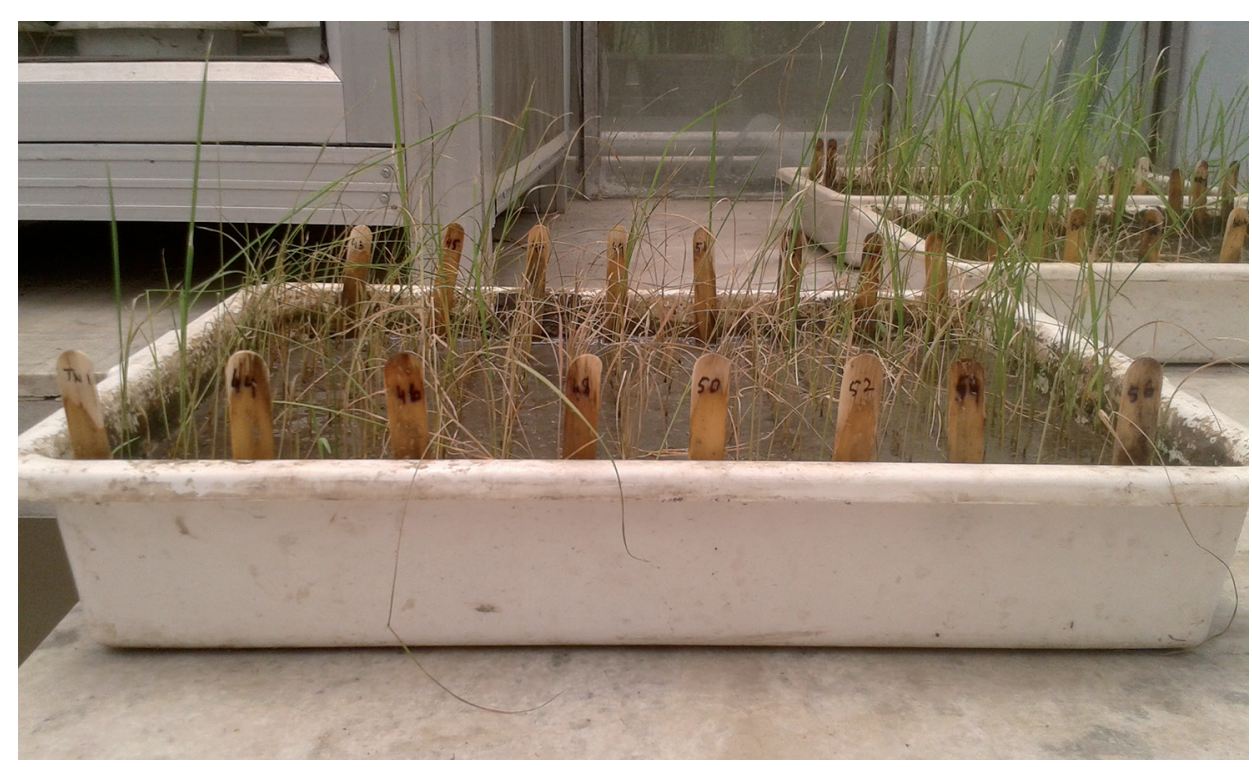

Figure 1. Standard seed box screening of rice genotypes under controlled conditions as per the technique given by Heinrichs et al. (1985)

$\mathrm{F}_{1}$ obtained from Pusa Basmati $1 \times$ MRST 3 cross was used to produce $\mathrm{F}_{2}, \mathrm{~B}_{1}$ (backcross with Pusa Basmati 1) and $\mathrm{B}_{2}$ (backcross with MRST 3) generations.

All the available generations of each cross along with concerned $F_{1}$ and parents were subjected to evaluation for BPH resistance under glass house conditions as per standard seed box screening technique (Heinrichs et al. 1985) (Figure 1) for finding out the inheritance pattern and gene action of the trait. The screening was conducted at a temperature of 28 to $30{ }^{\circ} \mathrm{C}$ and relative humidity of 70 to $80 \%$. The seeds were presoaked and sown in rows in $50 \times 35 \times 10 \mathrm{~cm}$ seed boxes along with susceptible check (TN 1). On an average, 20 seedlings per row were maintained per genotype. Ten day old seedlings were infested with first instar nymphs and adults of brown planthopper at the rate of eight to 10 per seedling. Approximately, one week after infestation, hopper burn symptoms were observed. When more than $90 \%$ of susceptible check (TN 1) showed wilting, the plants were scored individually based on scoring system proposed by the International Rice Research Institute (IRRI 1996) and each seedling was scored as 0 for no visible damage, 1 for partial yellowing of first leaf, 3 for partial yellowing of first and second leaves, 5 for pronounced yellowing or some stunting, 7 for mostly wilted plant but still alive and 9 for the completely wilted or dead plant.

For the purpose of genetic segregation, the plants with scores 1-5 were grouped into resistant class and those with score 7-9 into susceptible class as suggested by Rongbai et al. (2001). The segregation ratios of resistant to susceptible plants were subjected to goodness of fit between expected and observed values using Chi-square test. The calcu- 
lated Chi-square was computed by using the following formula of Snedecor and Cochran (1967).

$$
\chi^{2}=\sum \frac{(O-E)^{2}}{E}
$$

Where $\mathrm{O}=$ observed frequency,

$\mathrm{E}=$ expected frequency.

The calculated Chi-square value was tested for significance by comparing the table Chi-square value at 0.05 probability level and $(n-1)$ degrees of freedom, where ' $n$ ' is the number of classes of trait under consideration.

\section{Results}

The investigation was focused on to know the inheritance pattern and gene action of BPH resistance in the newly identified sources of rice. The data with respect to the screening and identification of BPH resistant sources revealed that the parents PHS 29 and MRST 3 showed a mean BPH score of less than 3.0 (Table S1).

Table 1. Segregation of plants for brown planthopper resistance in different generations derived from

TN $1 \times$ PHS 29 cross

\begin{tabular}{|l|c|c|c|c|c|c|}
\hline \multirow{2}{*}{ Generation } & \multirow{2}{*}{$\begin{array}{c}\text { Total } \\
\text { No. of plants }\end{array}$} & \multicolumn{3}{|c|}{ Segregation of plants } & \multirow{2}{*}{$\chi 2$ cal } & \multirow{2}{*}{$\begin{array}{c}\chi^{2} \text { tab } \\
(0.05,1 \mathrm{df})\end{array}$} \\
\cline { 3 - 5 } & & $\mathrm{R}$ & $\mathrm{S}$ & Ratio (R:S) & & \\
\hline TN 1 & 65 & 0 & 65 & & & \\
\hline PHS 29 & 45 & 42 & 3 & & & \\
\hline $\mathrm{F}_{1}$ & 42 & 0 & 42 & $0: 1$ & & 3.84 \\
\hline
\end{tabular}

$\mathrm{R}=$ Resistant $\mathrm{S}=$ Susceptible; $\mathrm{df}=$ degrees of freedom.

Table 2. Segregation of plants for brown planthopper resistance in different generations derived from Pusa Basmati $1 \times$ MRST 3 cross

\begin{tabular}{|c|c|c|c|c|c|c|}
\hline \multirow{2}{*}{ Generation } & \multirow{2}{*}{$\begin{array}{c}\text { Total } \\
\text { No. of plants }\end{array}$} & \multicolumn{3}{|c|}{ Segregation of plants } & \multirow{2}{*}{$\chi^{2} \mathrm{Cal}$} & \multirow{2}{*}{$\begin{array}{c}\chi^{2} \mathrm{tab} \\
(0.05,1 \mathrm{df})\end{array}$} \\
\hline & & $\mathrm{R}$ & $\mathrm{S}$ & Ratio (R:S) & & \\
\hline Pusa Basmati 1 & 42 & 0 & 42 & & & \\
\hline MRST 3 & 37 & 37 & 0 & & & \\
\hline $\mathrm{F}_{1}$ & 41 & 0 & 41 & $0: 1$ & & \\
\hline $\mathrm{F}_{2}$ & 172 & 16 & 156 & $1: 15$ & 2.73 & 3.84 \\
\hline $\mathrm{B}_{1}$ & 67 & 3 & 64 & $0: 1$ & 0.13 & 3.84 \\
\hline $\mathrm{B}_{2}$ & 94 & 16 & 78 & $1: 3$ & 3.19 & 3.84 \\
\hline
\end{tabular}

$R=$ Resistant; $\mathrm{S}=$ Susceptible; $\mathrm{B}_{1}=$ Backcross with $\mathrm{P}_{1}$ (Pusa Basmati 1); $\mathrm{B}_{2}=$ Backcross with $\mathrm{P}_{2}$ (MRST 3); $\mathrm{df}=$ degrees of freedom. 
As far as inheritance studies are concerned, all the plants of $\mathrm{F}_{1}$ generation obtained from TN $1 \times$ PHS 29 cross were found to be susceptible to $\mathrm{BPH}$, indicating recessive nature of resistance. Screening of $\mathrm{F}_{2}$ generation showed that 124 out of 152 plants were susceptible to BPH whereas, 28 plants were resistant (Table 1).

In case of Pusa Basmati $1 \times$ MRST 3 cross, all the plants of $F_{1}$ were found to be susceptible to BPH. Out of 172 F2 plants, 156 were found susceptible to BPH. In $\mathrm{B}_{1}$ generation, 64 plants were found susceptible to BPH out of 67 plants. Whereas, in case of $\mathrm{B}_{2}$ generation, 78 plants out of 94 were susceptible to BPH (Table 2).

\section{Discussion}

Host plant resistance is a sustainable and eco-friendly way of tackling the damage caused by insects. Brown planthopper is one of the notorious pests of rice crop, affecting the crop yields significantly. To breed for BPH resistant rice varieties, there is a need to identify the sources of resistance and find out the nature of inheritance, gene action and number of genes controlling the trait. During the present investigation, the genetic segregation of $F_{2}$ generation derived from TN $1 \times$ PHS 29 cross followed 1:3 (resistant: susceptible) ratio as per chi-square analysis, suggesting monogenic recessive nature of BPH resistance in PHS 29 genotype. The monogenic recessive nature of $\mathrm{BPH}$ resistance was also reported by Khush et al. (1985) in ARC 10550 rice accession. Rongbai et al. (2001) reported that resistance against Pantnagar biotype of BPH in 94-42-5-1 genotype is also governed by single recessive gene. The presence of single recessive gene controlling BPH resistance was also mentioned by Martinez and Khush (1974), Sidhu and Khush (1978), Verma et al. (2001) and Kiran et al. (2014).

In case of Pusa Basmati 1 x MRST 3 cross, all the plants of $F_{1}$ were found to be susceptible to $\mathrm{BPH}$ indicating recessive nature of resistance. The $\mathrm{F}_{2}$ generation derived from the selfing of $F_{1}$ segregated in the ratio of 1:15 (resistant $(\mathrm{R})$ : susceptible (S)) indicating digenic recessive nature of BPH resistance in MRST 3 parent. The results were also confirmed by the segregation pattern of $\mathrm{B}_{1}$ and $\mathrm{B}_{2}$ generations. The $\mathrm{B}_{2}$ generation followed a ratio of 1:3 (R:S), thereby indicating the digenic recessive nature of resistance.

The digenic recessive nature of resistance was also reported by Rongbai et al. (2001) in parent 94-42-5-1 against Culong BPH biotype. Balakrishna and Satyanarayana (2013) also identified that BPH resistance was controlled by two genes (one dominant and one recessive) in donors Sinna Sivappu, Sudu Hondarawah and PTB 33. Deen et al. (2017) also reported that the inheritance pattern of different traits suggested that the BPH resistance in ARC10550 genotype is controlled by more than one gene. Since more the number of genes controlling a trait, more is the size of segregating generations needed to recover the desirable recombinants. The results of the present investigation suggest that while using PHS 29 genotype as resistance donor, relatively smaller size of segregating generations is needed as compared to that when MRST 3 is used as resistance donor.

Although diverse sources of resistance against BPH are available (Ling and Weilin 2016), a better understanding of relative importance of gene effects affecting the genetic variation of resistance will help rice breeders to formulate effective breeding programmes. 
As far as the gene action of BPH resistance in present study is concerned, the concerned trait in both the parents was governed by recessive genes, which indicates lack of dominance. These results indicate that employing pure line breeding method in segregating generations derived from crosses using PHS 29 or MRST 3 as one of the parents for development of rice varieties resistant to BPH will be quite useful. This is because the BPH resistance in PHS 29 and MRST 3 genotypes is governed by additive gene action and hence, rice improvement programmes must promote homozygosity of BPH resistance alleles for their effective expression.

\section{References}

Balakrishna, B., Satyanarayana, P.V. 2013. Genetics of brown planthopper (Nilaparvata lugens Stal.) resistance in elite donors of rice (Oryza sativa L.). The Bioscan 8:1413-1416.

Bosque-Perez, N.A., Buddenhagen, I.W. 1992. The development of host-plant resistance to insect pests: outlook for the tropics. In: Menken, S.B.J., Visser, J.H., Harrewijn, P. (eds), Proceedings of 8th International Symposium on insect-plant relationships, Dordrecht, Kluwer. pp. 235-249.

Brar, D.S., Virk, P.S., Jena, K.K., Khush, G.S. 2010. Breeding for resistance to planthoppers in rice. In: Planthopper: new threats to the sustainability of intensive rice production systems in Asia, IRRI. pp. 401427.

Deen, R., Ramesh, K., Padmavathi, G., Viraktamath, B.C., Ram, T. 2017. Mapping of brown planthopper [Nilaparvata lugens (Stål)] resistance gene (bph5) in rice (Oryza sativa L.). Euphytica 213:35-49.

Dupo, A.L., Barrion, A.T. 2009. Taxonomy and general biology of delphacid planthoppers in rice agroecosystems. In: Heong, K.L., Hardy, B. (eds), Planthoppers: New Threats to the Sustainability of Intensive Rice Production Systems in Asia, International Rice Research Institute, Los Baños, Philippines. pp. 3-156.

Gowda, S. 2009. Screening of rice germplasm against brown planthopper, Nilaparvata lugens (Stal.). In: Annual meeting of Entomological society of America held at Indian Apolis, USA. pp. 12-16.

Heinrichs, E.A., Medrano, F.G., Rapusas, H.R. 1985. Genetic evaluation for insect resistance in rice. IRRI, Los Baños, Philippines. pp. 1-356.

IRRI. 1996. Standard Evaluation System for Rice. IRRI, Manila, Philippines.

Jena, K.K., Jeung, J.U., Lee, J.H., Choi, H.C., Brar, D.S. 2006. High-resolution mapping of a new brown planthopper (BPH) resistance gene, Bph18(t), and marker-assisted selection for BPH resistance in rice (Oryza sativa L.). Theor. Appl. Genet. 112:288-297.

Khush, G.S., Karim, A.R., Angeles, E.G. 1985. Genetics of resistance of rice cultivar ARC10550 to Bangladesh brown planthopper biotype. J. Genet. 64:121-125.

Kiran, K.K., Rao, M.R.G., Veerangati, S.S., Rakesh, B. 2014. Study of inheritance of BPH resistance in two $\mathrm{F}_{2}$ populations of rice. Trends in Biosci. 7:861-863.

Ling, Y., Weilin, Z. 2016. Genetic and biochemical mechanisms of rice resistance to planthopper. Plant Cell Rep. 35:1559-1572.

Martinez, C.R., Khush, G.S. 1974. Sources and inheritance of resistance to brown planthopper in some breeding lines of rice. Crop Sci. 14:264-267.

Rongbai, L., Xueyi, Q., Sumei, W., Pandey, M.P., Pathak, P.K., Fenguan, H., Qing, L., Shanyu, L. 2001. Inheritance of resistance to brown planthopper in an Oryza rufipogon (Griff.) - derived line in rice. Curr. Sci. 80:1421-1423.

Sidhu, G.S., Khush, G.S. 1978. Genetic analysis of brown planthopper resistance in twenty varieties of rice, Oryza sativa. Theor. Appl. Genet. 53:199-203.

Snedecor, G.W., Cochran, W.G. 1967. Statistical Methods. $6^{\text {th }}$ edition, Ames, Iowa, The Iowa state University. Sogawa, K., Gallagher, K.D., Kenmore, P.P.E. 1994. Pest management in tropical paddy ecosystems. Japanese J. Trop. Agric. 38:361-368.

Sogawa, K., Liu, G.J., Shen, J.H. 2003. A review on the hyper-susceptibility of Chinese hybrid rice to insect pests. Chin. J. Rice Sci. 17:23-30. 
Tanaka, K., Matsumura, M. 2001. Development of virulence to resistant rice varieties in the brown planthopper, Nilaparvata lugens (Homoptera: Delphacidae), immigrating into Japan. J. Appl. Entomol. Zool. 35:529533.

Verma, V.K., Rastogi, N.K., Pophaly, D.J., Mishra, R.K. 2001. Genetics of resistance to brown planthopper (Nilaparvata lugens Stal.) in rice. Oryza 38:6-8.

Wang, Y., Wang, X., Yuan, H., Chen, R., Zhu, L., He, R., He, G. 2008. Responses of two contrasting genotypes of rice to brown planthopper. Mol. Plant-Microbe Interact. 21:122-132.

Watanabe, T., Fabellar, L.T., Almazan, L.P., Rubia, E.G., Heong, K.L., Sogawa, K. 1997. Quantitative evaluation of growth and yield of rice plants infested with rice planthoppers. In: Kropff, M.J. et al. (eds), Applications of systems approaches at the field level, Kluwer Academic Publishers, Dordrecht. pp. 365382 .

\section{Electronic Supplementary Material (ESM)}

Electronic Supplementary Material (ESM) associated with this article can be found at the website of CRC at https://akademiai.com/loi/0806

Electronic Supplementary Table S1. Standard seed box screening of advanced breeding lines of rice for brown planthopper resistance under controlled conditions 